\title{
VARIATION OF THE DNA CONTENT OF MORPHOLOGICALLY NORMAL AND ABNORMAL SPERMATOZOA IN MICE SUSCEPTIBLE TO IRREGULAR MEIOTIC SEGREGATION
}

\author{
R. STOLLA AND A. GROPP \\ Gynäkologische und Ambulatorische Tierklinik der Universität München, and \\ Institut für Pathologie der Medizinischen Hochschule, Lübeck, \\ Federal Republic of Germany
}

(Received 20th Fune 1973)

Summary. The DNA content of morphologically normal spermatozoa from the laboratory mouse (Mus musculus), the tobacco mouse ( $M$. poschiavinus) and $M$. musculus $\times M$. poschiavinus $\mathrm{F}_{1}$ hybrids was determined by u.v. photometry. The DNA content was also determined in morphologically abnormal spermatozoa from $\mathrm{F}_{1}$ males.

In contrast to the parental strains, the $F_{1}$ hybrids showed a high incidence of aneuploid secondary spermatocytes. This was due to irregular meiotic anaphase I segregation. The variation of the DNA content in morphologically normal spermatozoa was significantly higher in the $F_{1}$ hybrids than in the laboratory mouse and the tobacco mouse. This was attributed to the presence of a considerable fraction of aneuploid spermatozoa with a hypo- or hypermodal variation of the haploid chromosomal complement.

The frequency of teratospermy was increased in $F_{1}$ males. The morphologically abnormal spermatozoa showed a higher mean DNA content and a considerably larger standard deviation of the DNA content than that observed in morphologically normal spermatozoa. Spermatozoa carrying extreme deviations from the modal chromosome number seemed to be more frequent in this group than in the morphologically normal spermatozoa of the $F_{1}$ males.

It is concluded that even though a majority of the aneuploid spermatogenic precursor cells may develop to morphologically normal (yet chromosomally unbalanced) spermatozoa, a minority may give rise to morphologically abnormal spermatozoa. There is evidence that neardiploid spermatozoa are due to a failure of the second meiotic division.

\section{INTRODUGTION}

Chromosomal disorders in human (Carr, 1965, 1970; Boué \& Boué, 1973) and other mammalian (McFeely, 1967; Ford, 1970) embryos leading to developmental abnormalities and selective prenatal elimination result either from 
irregular meiotic division during gametogenesis or from abnormal steps during or following the process of fertilization. Triploidy seems to be due to disturbances associated with fertilization and early cleavage (Edwards, Yuncken, Rushton, Richards \& Mittwoch, 1967), whereas mono- and trisomy are mainly caused by abnormal meiotic segregation in the course of oogenesis and spermatogenesis. The question of whether or not chromosomally unbalanced precursor cells permit the maturation of morphologically normal gametes possessing normal fertilizing properties, however, needs further elucidation. Means for a closer study of this problem are provided by the use of the chromosomally heterozygous $\mathrm{F}_{1}$ hybrids of the laboratory mouse (Mus musculus) and the tobacco mouse ( $M$. poschiavinus). As shown previously (Gropp, Tettenborn \& von Lehmann, 1970; Tettenborn \& Gropp, 1970), hybrid males produce more than $50 \%$ aneuploid secondary spermatocytes resulting from irregular segregation in meiotic anaphase I. Evidence has been presented that at least a majority of the chromosomally unbalanced precursor cells develop to mature, functioning spermatozoa. This assumption is based (1) on the observation of a considerably greater variation of Feulgen-DNA values of the morphologically normal spermatozoa in the $F_{1}$ males than in the parental strains (Döring, Gropp \& Tettenborn, 1972), and (2) on the finding that $F_{1}$ hybrid males mated with female laboratory mice generate about $50 \%$ or more aneuploid (monosomic or trisomic) zygotes (Gropp, 1973; A. Gropp, D. Giers, M. D. Burtenshaw, H. Clegg, E. P. Evans and C. E. Ford, in preparation).

The aim of the present study was to attempt to corroborate the data of Döring et al. (1972) resulting from Feulgen-DNA measurements of morphologically normal spermatozoa by determining the sperm DNA content more exactly with u.v. photometry and thus strengthening the evidence for the assumption that aneuploid spermatocytes possess the capacity to develop to morphologically and functionally normal spermatozoa. Conversely, the study of Döring et al. (1972) indicated the presence of an increased rate of teratospermy in $F_{1}$ males. Since this phenomenon may possibly be associated with the aneuploidy occurring among the spermatocyte precursor cells (see also Leidl, Stolla \& Botzenhardt, 1973), DNA measurements of abnormal spermatozoa also seemed to be of interest.

\section{MATERIALS AND METHODS}

Animals

Six males, between $2 \frac{1}{2}$ and 5 months old, of each of the following groups were used in DNA measurements of the spermatozoa: Group $\mathrm{A}=$ Mus musculus (laboratory mouse, strain NMRI Han.), Group B $=M$. poschiavinus (tobacco mouse), and Group $\mathrm{C}=M$. poschiavinus ${ }^{\star} \times \mathrm{NMRI} q \mathrm{~F}_{1}$ hybrids.

In contrast to the laboratory mouse which possesses a somatic karyotype of forty acrocentric chromosomes $(2 n=40, \mathrm{NF} \doteq 40)$, the diploid chromosomal set of $M$. poschiavinus contains fourteen metacentrics and twelve acrocentrics $(2 n=26)$, the seven pairs of metacentrics being derived from centric Robertsonian fusions (Gropp et al., 1970). Therefore, the fundamental number (NF) of chromosome arms of this species/subspecies remains unchanged $(\mathrm{NF}=40)$. 
The somatic chromosome number of the $F_{1}$ hybrids is thirty-three, including the seven metacentrics $(2 n=33 ; \mathrm{NF}=40)$. Despite structural heterozygosity, there is complete homology of the arms of the seven tobacco mouse metacentrics with the corresponding acrocentrics of the laboratory mouse. This is demonstrated by staining procedures (Zech, Evans, Ford \& Gropp, 1972; Gropp, Winking, Zech \& Müller, 1972) and by the presence of seven regular trivalents in meiotic preparations of primary spermatocytes. Nevertheless, these trivalents are responsible for a high incidence of irregular meiotic anaphase I segregation, although the respective rates differ considerably for the individual trivalents among the series of seven. As revealed by chromosome counts of metaphase II figures, the incidence of euploid to aneuploid secondary spermatocytes is $46 \cdot 2 \%: 53 \cdot 8 \%$ in NMRI $\times$ tobacco mouse $F_{1}$ hybrids, $95 \cdot 2 \%: 4 \cdot 8 \%$ in the NMRI Han laboratory mouse and $93.1 \%: 6.9 \%$ in the tobacco mouse (Tettenborn \& Gropp, 1970; Döring et al., 1972).

\section{Evaluation of the morphology of spermatozoa and determination of the DNA content}

Sperm fluid expressed from the vasa deferentia was washed by isotonic saline added to a drop at the edge of the slide. The smear was then freshly stained with eosin-nigrosin (Hancock, 1951) for the evaluation of sperm morphology.

For DNA mesurements, sperm fluid similarly obtained from the vasa deferentia immediately after killing the animal was rapidly diluted in a tenfold amount of isotonic saline followed by centrifugation for $5 \mathrm{~min}$ at 800 to 1000 $\mathrm{rev} / \mathrm{min}$. After discarding the supernatant, the centrifuged spermatozoa were carefully smeared on quartz slides, covered with glycerol (index of refraction $=1.455$ ) and a quartz cover glass. In fifty morphologically normal spermatozoa of each of the six males per group, the total extinction $(\Sigma E)$ at $260 \mathrm{~nm}$ (maximum for DNA), $280 \mathrm{~nm}$ (maximum for proteins) and $313 \mathrm{~nm}$ (correction for nonspecific light loss) was recorded using the Universal Microspectrophotometer ZEISS (UMSP I). On the basis of these measurements, the DNA content per sperm head (M) was calculated according to the formula $\mathrm{M}=0.92 \Sigma \mathrm{E}_{260 \mathrm{~nm}}$ $-0.75 \Sigma E_{280 \mathrm{~nm}}-0.25 \Sigma \mathrm{E}_{313 \mathrm{~nm}}$ (see Stolla, 1968). In addition, slides from two more $F_{1}$ hybrid males (Group D) were used for similar measurements of spermatozoa presenting distinct malformations of the head. Again, fifty cells were evaluated per animal.

\section{RESULTS}

\section{$D \mathcal{N A}$ content of morphologically normal spermatozoa}

The levels of DNA determined for fifty morphologically normal spermatozoa of the six animals $(\mathrm{N}=300)$ belonging to each of the three groups of mice under investigation revealed a considerably higher standard deviation (S.D.) in the $F_{1}$ hybrids (Table 1) than in both parental strains, the laboratory and the tobacco mouse. This result was based on the finding of a characteristically wide range of the S.D. in each of the six individual mice belonging to Group C compared with mice of Groups A and B (Table 1). Similar evidence emerged from the presence of a significant difference in the cumulative values of the S.D. of animals of Group C ( $F_{1}$ hybrids) and of Groups A and B as represented in 


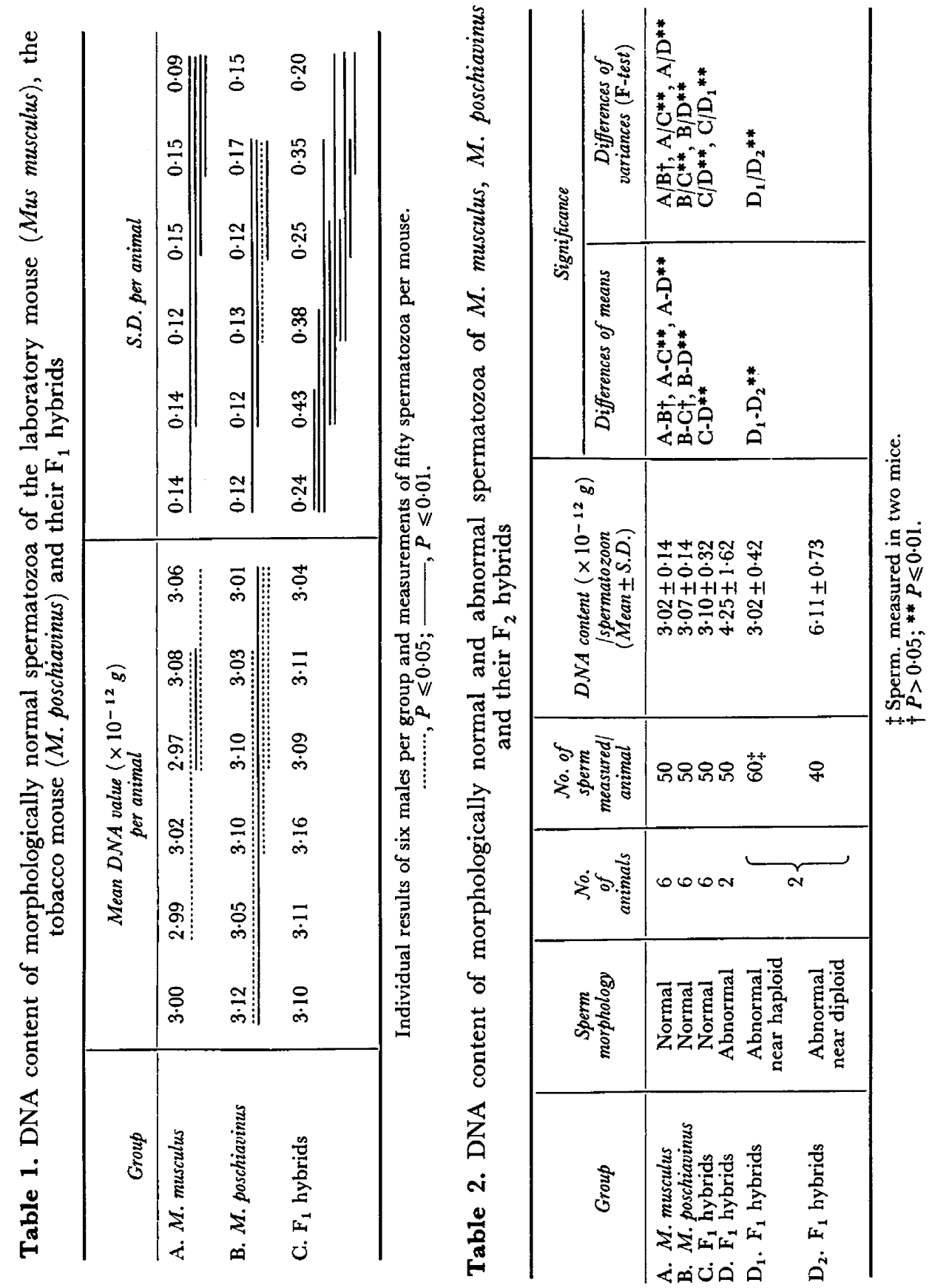


Table 2. As a result, the distribution curve of the DNA measurements of $F_{1}$ hybrid sperm heads $(\mathrm{N}=300)$ was broader than that of the parental strains and showed a lower peak (Text-fig. 1).

The inter-individual variation of the S.D. of the DNA content per sperm head of the animals belonging to the parental strains (Table 1) was moderate though, in part, more important. By contrast, the six $F_{1}$ hybrids showed considerable variation between S.D. \pm 0.20 and $\pm 0.43(P \leqslant 0.01)$. The composite presentation of the individual curves of the six animals in Text-fig. 2 further visualizes these differences. The collective curve derived from the single curves corresponds to that represented in Text-fig. 1.

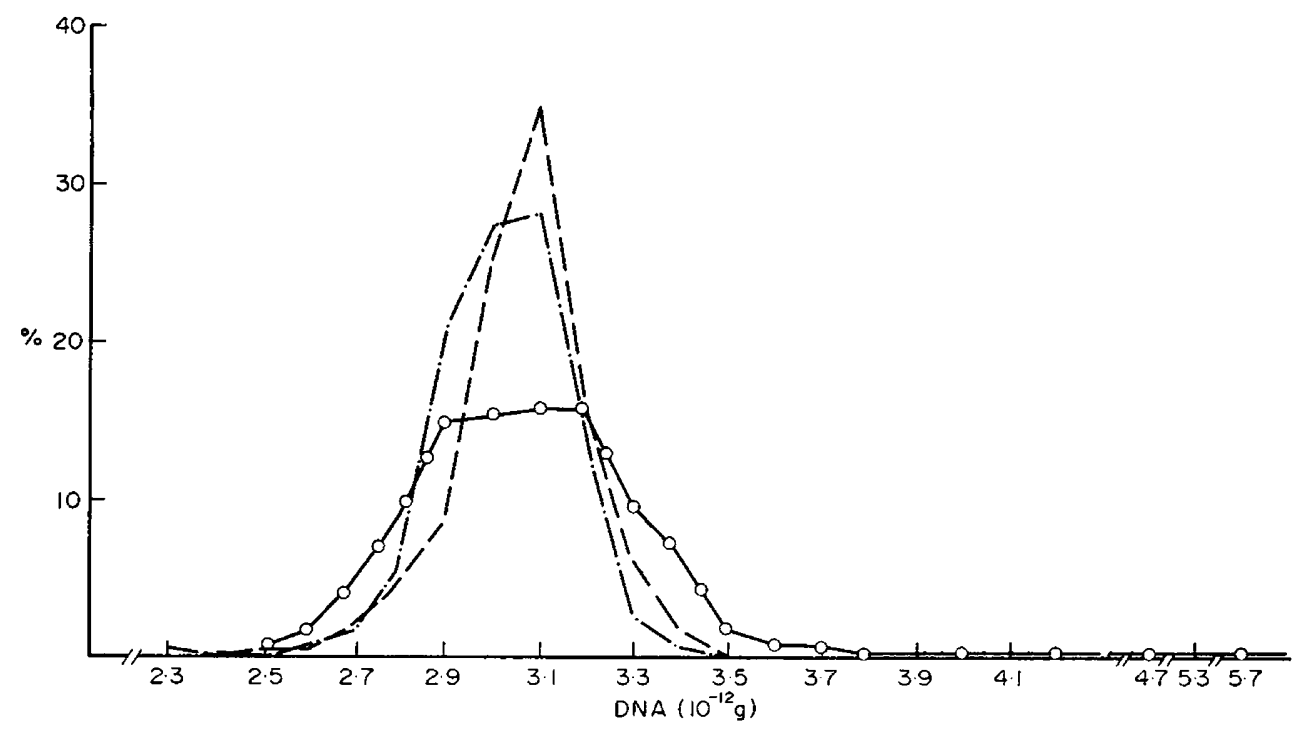

TEXT-FIG. 1. Distribution of the DNA content of morphologically normal spermatozoa from (---) Mus musculus (NMRI), (- -- M. poschiavinus and $(-) F_{1}$ hybrids. (Six animals per group, fifty spermatozoa per animal; $\mathrm{N}=300$.) Class interval $=0.1 \times 10^{-12} \mathrm{~g}$.

Extreme hypermodal DNA measurements prevailed slightly within the total population of morphologically normal $F_{1}$ spermatozoa (Text-fig. 1). As a result, the mean value of the DNA content of the $F_{1}$ hybrids was higher than that of both parental strains. The statistical significance of this difference, however, can only be assumed by comparison with the laboratory mouse $(P \leqslant 0.01$; the calculation is based on the mean values per animal). The variation of the mean values between the laboratory and the tobacco mouse (A and B) is not significant $(P>0.05)$.

The comparison of the mean values of the DNA content per sperm head revealed distinct and, in part, highly significant differences between the individual males belonging to the Groups $A$ and $B$ (Table 1 ). In the $F_{1}$ hybrids, such differences could not be ascertained because of the greater standard variations. 


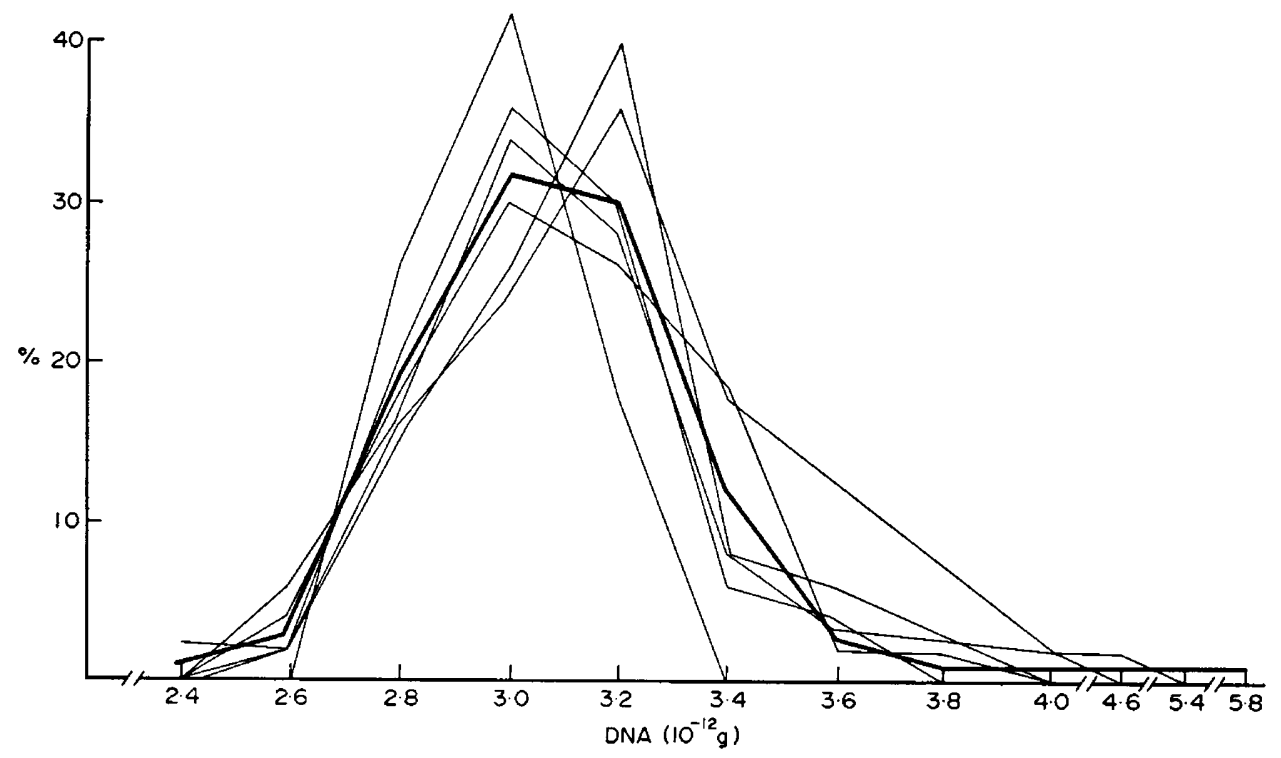

TexT-FIG. 2. Individual distribution curves of the DNA content of morphologically normal spermatozoa $(N=50)$ from six $F_{1}$ male mice ( - , thin continuous lines) and a collective curve (- thick continuous line) representing the average of the individual variances. The slight difference of this curve from that of Text-fig. 1 is due to the use of broader classes $\left(0.2 \times 10^{-12} \mathrm{~g}\right)$ in this figure.

\section{Morphologically abnormal spermatozoa and measurements of the DNA content}

Döring et al. (1972) reported $9 \cdot 6 \%$ of abnormal spermatozoa in counts from nine $\mathrm{F}_{1}$ males while the respective values in the NMRI strain (nine specimens) and in the tobacco mouse (seven specimens) were $2.7 \%$ and $1.7 \%$. Further counts in the course of this study comprising a total number of 5650 spermatozoa from five $F_{1}$ males yielded $8.1 \%$ abnormal/malformed spermatozoa (Table 3 ). Though slightly lower, this frequency is in agreement with that observed in the earlier study. It is, however, significantly higher than the corresponding values found in the parental strains $(P \leqslant 0 \cdot 01)$. Differential counts considering the severity and type of malformation (Table 3 and Plate 1) revealed about

Table 3. Differential counts of morphologically abnormal spermatozoa from five $\mathrm{F}_{1}$ hybrids of Mus musculus $(\mathrm{NMRI}) \times M$. poschiavinus

\begin{tabular}{c|c|c|cccc|cc}
\hline \multirow{2}{*}{$\begin{array}{c}\text { Mouse } \\
\text { no. }\end{array}$} & $\begin{array}{c}\text { No. of } \\
\text { sperm. }\end{array}$ & $\begin{array}{c}\text { No. of } \\
\text { normal } \\
\text { sperm. }\end{array}$ & $\begin{array}{c}\text { Slight } \\
\text { head } \\
\text { anomalies }\end{array}$ & $\begin{array}{c}\text { Severe } \\
\text { head mal- } \\
\text { formations }\end{array}$ & $\begin{array}{c}\text { 'Giant } \\
\text { head' }\end{array}$ & $\begin{array}{c}\text { Doubling } \\
\text { of the } \\
\text { tail }\end{array}$ & $\begin{array}{c}\text { Total no. } \\
\text { of anomalies }\end{array}$ & $\begin{array}{c}\text { Mean } \% \\
\text { of anomalies }\end{array}$ \\
\hline 1 & 600 & 559 & 22 & 5 & 13 & 1 & 41 & $6 \cdot 83$ \\
2 & 1200 & 1087 & 33 & 51 & 24 & 5 & 113 & $9 \cdot 42$ \\
3 & 1400 & 1271 & 40 & 58 & 23 & 8 & 129 & $9 \cdot 21$ \\
4 & 850 & 789 & 18 & 11 & 30 & 2 & 61 & $7 \cdot 18$ \\
5 & 1600 & 1484 & 31 & 40 & 29 & 16 & 116 & $7 \cdot 25$ \\
\hline Total & 5650 & 5190 & 144 & 165 & 119 & 32 & 460 & $8 \cdot 1 \%$ \\
\hline
\end{tabular}




\section{PLATE 1}

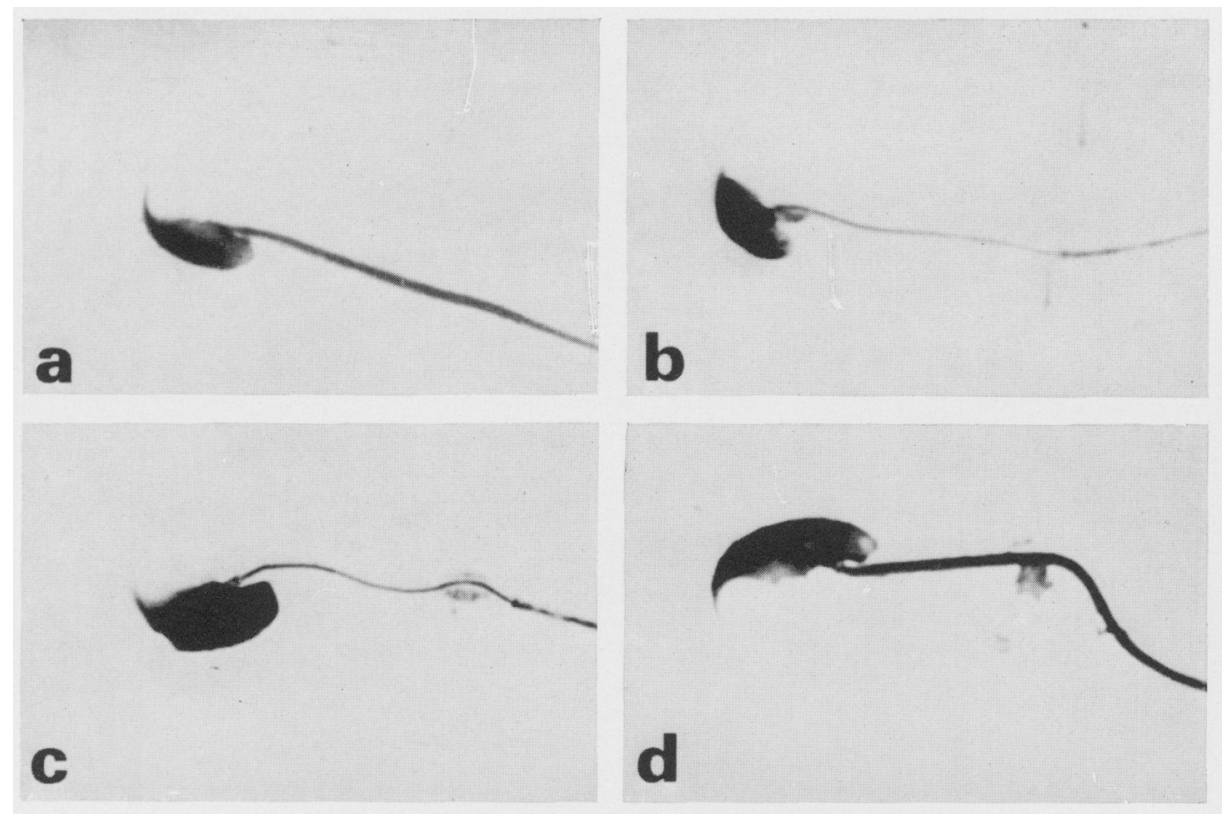

Mouse spermatozoa. Eosin-nigrosin, $\times 2230$. (a) Morphologically normal spermatozoon. (b) Slight abnormality. (c) Severe abnormality and enlarged head. (d) 'Giant head' abnormality. 
equal frequencies of slight and severe anomalies of the sperm head and giant size of the sperm head (ranging between 2.1 and $2.9 \%$ ).

The measurement of 100 spermatozoa with malformations of the head of all three types obtained from semen smears of two $F_{1}$ males (Table 2, $D_{1}$ and $D_{2}$ ) disclosed a considerably higher S.D. of the DNA content than that observed in morphologically normal spermatozoa from $F_{1}$ hybrids. As shown by the curve of the frequency distribution (Text-fig. 3), two different peaks representing two populations of abnormal spermatozoa with different ranges of DNA content could be distinguished. Thus, an arbitrary subdivision of 100 abnormal spermatozoa into two groups (Table $2, \mathrm{D}_{1}$ and $\mathrm{D}_{2}$ ) according to values of the DNA content below or above the mean value of the population reveals the presence of

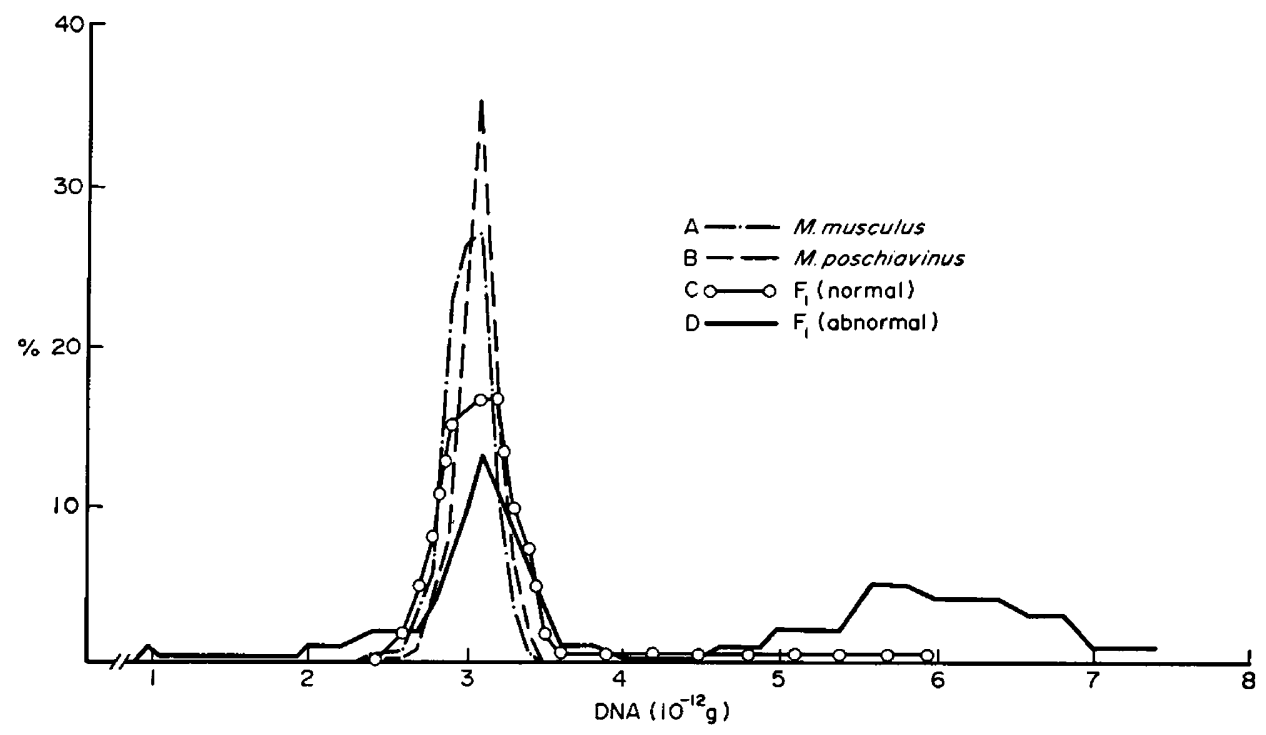

TeXT-Fig. 3. Distribution of the DNA content of malformed spermatozoa (Group D) from $F_{1}$ hybrids (fifty spermatozoa measured from each of two mice; $N=100$ ) compared with the curves obtained from measurements of morphologically normal spermatozoa (see Text-fig. 1). Class interval $=0.1 \times 10^{-12} \mathrm{~g}$.

a near-haploid population and another displaying near-diploid mean DNA values. The mean S.D. of the morphologically abnormal near-haploid spermatozoa of $\mathrm{F}_{1}$ males significantly $(P \leqslant 0.01)$ exceeded that of the morphologically normal spermatozoa of $F_{1}$ hybrids (Table 2). Furthermore, the value of S.D. in abnormal spermatozoa with a near-diploid DNA content was about twice that found in the abnormal spermatozoa belonging to the near-haploid range $(P \leqslant 0 \cdot 01)$.

\section{DISGUSSION AND CONGLUSIONS}

Ability of aneuploid spermatogenic precursor cells to develop to morphologically normal spermatozoa

Presumably, the curves representing the variance of the DNA content of 
individual spermatozoa of the NMRI-strain mouse and of the tobacco mouse correspond to the mean distribution of a population of chromosomally balanced spermatozoa. This conclusion can be drawn from the rarity of abnormal chromosome counts in meiotic metaphase II figures (secondary spermatocytes) in these strains (Tettenborn \& Gropp, 1970; Döring et al., 1972). Converse evidence from $F_{1}$ hybrids (laboratory mouse $\times$ tobacco mouse) supports the assumption that the considerably greater variation of the DNA values of morphologically normal and mature spermatozoa results from the presence of a significant proportion of aneuploid cells with a hypo- or hypermodal variation of the haploid chromosomal complement. This interpretation is in agreement with the occurrence of more than $50 \%$ of chromosomally unbalanced secondary spermatocytes in $\mathrm{F}_{1}$ hybrids (Tettenborn \& Gropp, 1970). The proportion of chromosomal aberrations among spermatozoa can be approximated by the extent to which the deviation of the DNA content of spermatozoa of the $F_{1}$ hybrids exceeds that observed in the parental strains, but an accurate estimation is not possible. There is evidence that eventually a large proportion, if not a majority, of the aneuploid spermatogenic precursor cells develop into mature, though genetically defective, spermatozoa. Samples of morphologically normal spermatozoa (and not only teratospermatozoa) may therefore include considerable fractions of chromosomally unbalanced spermatozoa. This is of some importance for the morphological evaluation of sperm samples in medical andrology. These results confirm earlier observations of Döring et al. (1972) obtained by relative Feulgen-DNA measurements of spermatozoa from $F_{1}$ hybrid males (laboratory mouse $\times$ tobacco mouse). Nevertheless, the measurements in the u.v. range, as reported in the present study, permit a more exact evaluation of the variation of the DNA content and, therefore, a more reliable proof of the presence of spermatozoa containing either a hypo- or hypermodal chromosomal set.

Factors influencing the distribution curve of the DNA content of morphologically normal spermatozoa of $F_{1}$ hybrids

The shape of the distribution curve of the DNA content of $F_{1}$ spermatozoa lends support to the assumption that the lack or the extra acquisition of only one or possibly two chromosomes prevails among the chromosomal aberrations of spermatozoa while the incidence of extreme deviations is rather small. In fact, hypomodal or hypermodal chromosome numbers lower than 17 or exceeding $23(n=\mathrm{NF} / 2=20)$ have been shown to be rather infrequent in secondary spermatocytes of $F_{1}$ hybrids (Döring et al., 1972). There is, however, a marked shift to a higher mean value of the DNA content per spermatozoon in $F_{1}$ hybrid males compared with that found in the parental strains, though it is significant only by comparison with the laboratory mouse.

In any interpretation of this observation, it is necessary to consider the possibility of a higher representation of extreme hypermodal variants, and that some extreme hypomodal variants may eventually be eliminated during spermateleosis. The comparative analysis of DNA histograms of spermatozoa obtained from the ductus deferens of $F_{1}$ males and from the uterus and tube of females shortly after mating with the same males (Langenbeck \& Gropp, 1973) also 
supports the assumption of a preferential loss of carriers of extreme chromosomal aberrations before they arrive in the uterus. The importance of such factors of prezygotic selection against aneuploid spermatocytes and spermatozoa are, however, probably limited to a small number of cells with extreme chromosomal imbalance since it has been shown that up to $60 \%$ of aneuploid zygotes with an almost equal distribution of hypo- or hypermodal values may occur in preimplantation embryos resulting from matings of $\mathrm{F}_{1}$ males with laboratory strain females (A. Gropp, D. Giers, M. D. Burtenshaw, H. Clegg, E. P. Evans and C. E. Ford, in preparation).

As shown in Text-fig. 2, considerable differences in the mean deviation and in the shape of the distribution curves of the DNA content per sperm cell exist between the individual $F_{1}$ males. At the level of the single individual, at least for some animals, there is an over-representation of hypermodal values. Quantitative and qualitative variations of the proportion of aneuploid spermatozoa present in the individual sperm samples are clearly responsible for the differences of the deviation of the DNA content between the $F_{1}$ animals. In fact, recent results (A. Gropp and D. Giers, unpublished work) provide evidence for the existence of slight to more marked differences in the fertility rate between individual $F_{1}$ hybrid males. They correspond to similar, though not statistically significant, variations of the rate of irregular meiotic segregation (see also Döring et al., 1972; Cattenach \& Moseley, 1973) of these hybrids. The factors involved in the origin of these inter-individual differences are still unknown.

\section{Aneuploidy of spermatogenic precursor cells and teratospermy in $F_{1}$ males}

The distribution curves of the DNA content of the morphologically abnormal near-haploid and near-diploid spermatozoa suggest that in these groups the proportion of extreme deviations from the modal chromosome number is considerably higher than in the morphologically normal spermatozoa of the $F_{1}$ males. Nevertheless, the rate of $8.1 \%$ of morphologically abnormal spermatozoa found in $\mathrm{F}_{1}$ males, though significantly higher than the respective values of $1.7 \%$ and $2.7 \%$ observed in the parental strains, is comparatively low considering the marked aneuploidy shown to occur in the spermatogenic precursor cells (secondary spermatocytes). The conclusion can be drawn that even though a majority of the aneuploid spermatogenic cells have a chance to develop to morphologically normal spermatozoa, at least a minority, especially those spermatocytes with extreme hypo- or hypermodal chromosomal aberrations, give rise to morphologically abnormal sperm cells.

The percentage of the near-diploid spermatozoa of $F_{1}$ males is rather low. Two possible mechanisms could explain the origin of this condition, which was most often present in spermatozoa with a 'giant head': failure of the second meiotic division, or restitution after an incomplete second meiotic division. While the near-diploidy found in these spermatozoa refers to a near-diploid amount of DNA, it does not necessarily correspond to a diploid chromosomal complement which would be the result of a failure of the first meiotic division. The finding that the standard deviation of the DNA content of near-diploid spermatozoa is about double that of near-haploid sperm cells, however, would be expected if the irregular modal distribution of the chromosomal material in 
anaphase I is not followed by the splitting of the DNA values in the second meiotic division.

In contrast to the morphologically normal yet aneuploid spermatozoa, the abnormal sperm cells probably fail to take part in the fertilization process. Evidence for this assumption is provided by a study of spermatozoa washed from the uterus and the oviducts after time-controlled matings of $F_{1}$ males (Langenbeck \& Gropp, 1973). Morphologically abnormal spermatozoa shown to be present in the ductus deferens and in the uterus were virtually nonexistent in the oviduct.

Inter-individual variation of the mean DNA content per spermatozoon in the laboratory mouse and the tobacco mouse

The differences between the mean values of the DNA content per spermatozoon and also between the respective S.D. of individual males of the laboratory mouse and of the tobacco mouse cannot be reconciled easily with the so-called 'constancy-hypothesis' of DNA. This hypothesis postulates that the chromosomal complement of a species is an invariable characteristic, guaranteeing a constant DNA content within the species except in synthesizing nuclei or in cases of intraspecific chromosomal polymorphism and of aberrations (Boivin, Vendrely \& Vendrely, 1948; James, 1965). It is, therefore, difficult to interpret the observed inter-individual variations of the DNA values in the sperm cells of the two strains (or species). Spermatids and mature spermatozoa do not synthesize DNA (Gledhill, 1966; Gledhill, Gledhill, Rigler \& Ringertz, 1966), and aneuploid spermatocytes are rare in $M$. musculus and in $M$. poschiavinus in contrast to their $\mathbf{F}_{1}$ hybrids (Tettenborn \& Gropp, 1970). Similar variations between individuals found in human spermatozoa (Sandritter \& Grosser, 1964) and in those of several mammalian species (Leidl \& Stolla, 1969; Stolla, 1972) have been attributed to the presence of variable amounts of 'additional DNA' or of 'luxury DNA' in the sense of a genetically inactive DNA (Krzanowski \& Mackowska, 1969). Genetically inactive fractions of repetitive DNA have in fact been shown to be present in the mouse in a proportion of about $10 \%$ of the total DNA (Britten \& Kohne, 1968; Walker, Flamm \& McLaren, 1969; Jones \& Robertson, 1970). Moreover, preliminary results indicate the existence of inter-individual differences of this DNA fraction in the tobacco mouse (K. W. Jones, I. Purdom and A. Gropp, unpublished work) similar to comparable findings in man (Craig-Holmes \& Shaw, 1971; Jones \& Corneo, 1971). Though speculative, it is tentatively assumed that variations of this fraction of genetically inactive DNA are responsible for the inter-individual differences of the DNA content observed in the sperm cells of the laboratory and the tobacco mouse.

\section{ACKNOWLEDGMENTS}

This study was supported by a grant No. Gr 71/33 (to A.G.) of the Deutsche Forschungsgemeinschaft. We are indebted to Dr H. Vaupel (Munich), Mr G. Langenbeck (Bonn), Dr L. Döring and Miss G. Noack (Lübeck) for valuable technical help and to Professor G. H. Waring (Carbondale, Ill., U.S.A.) for his 
help in the preparation of the English text. We also express our gratitude to Professor W. Leidl who stimulated this work considerably.

\section{REFERENCES}

Boivin, A., Vendrely, R. \& Vendrely, C. (1948) L'acide désoxyribonucléique du noyau cellulaire, dépositaire des caractères héréditaires; arguments d'ordre analytique. C. r. hebd. Séanc. Acad. Sci., Paris, 226, 1061.

BouÉ, J. \& Boú, A. (1973) Évaluation des erreurs chromosomiques au moment de la conception. Biomedicine, $18,372$.

Britten, R. J. \& Kohne, D. E. (1968) Repeated sequences in DNA. Science, N.Y. 161, 529.

CARr, D. H. (1965) Chromosome studies in spontaneous abortions. Obstet. Gynec., N. Y. 26, 308.

CARr, D. H. (1970) Chromosome abnormalities and spontaneous abortions. In Human Population Cytogenetics, Pfizer Medical Monograph No. 5, p. 103. Edinburgh University Press.

Cattenach, B. M. \& Moseley, H. (1973) Non-disjunction and reduced fertility caused by the tobacco mouse metacentric chromosomes. Cytogenetics, 12, 264.

Craig-Holmes, A. P. \& Shaw, M. W. (1971) Polymorphism of human constitutive heterochromatin. Science, $\mathcal{N} . \Upsilon .174,702$.

Döring, L., Gropp, A. \& Tettenborn, U. (1972) DNA content and morphological properties of presumably aneuploid spermatozoa of tobacco mouse hybrids. F. Reprod. Fert. 30, 335.

Edwards, J. H., Yuncken, C., Rushton, D. I., Richards, S. \& Mittwoch, U. (1967) Three cases of triploidy in man. Cytogenetics, 6,81 .

Ford, C. E. (1970) The population cytogenetics of other mammalian species. In Human Population Cytogenetics, Pfizer Medical Monograph No. 5, pp. 222-239. Edinburgh University Press.

GLEDHILL, B. L. (1966) Studies on the DNA content, dry mass and optical area of bull spermatozoal heads during epididymal maturation. Acta vet. scand. 7, 131.

Gledhill, B. L., Gledhill, M. P., Rigler, R. \& Ringertz, N. R. (1966) Changes in deoxyribonucleoprotein during spermiogenesis in the bull. Expl Cell Res. 41, 652.

Gropp, A. (1973) Reproductive failure due to fetal aneuploidy in mice. Proc. 7 th Wld Congr. Fert. Steril., Tokyo/Kyoto, 1971, Excerpta med. Int. Congr. Ser. 278, 326-330.

Gropp, A., Tettenborn, U. \& von Lehmann, E. (1970) Chromosomenvariation vom Robertson schen Typus bei der Tabakmaus, M. poschiavinus, und ihren Hybriden mit der Laboratoriumsmaus. Cytogenetics, $9,9$.

Gropp, A., Winking, H., Zech, L. \& MülLeR, H. (1972) Robertsonian chromosomal variation and identification of metacentric chromosomes in feral mice. Chromosoma, 39, 265.

HANCOCK, J. L. (1951) A staining technique for the study of temperature-shock in semen. Nature, Lond. $167,323$.

JAMES, J. (1965) Constancy of nuclear DNA and accuracy of cytophotometric measurement. Cytogenetics, $4,19$.

Jones, K. W. \& CoRneo, G. (1971) Location of satellite and homogeneous DNA sequences on human chromosomes. Nature, New Biol. 233, 268.

Jones, K. W. \& Robertson, F. W. (1970) Localisation of reiterated nucleotide sequences in Drosophila and mouse by in situ hybridisation of complementary RNA. Chromosoma, 31, 331.

Krzanowski, M. \& Mackowska, R. (1969) Differences in DNA content in the spermatozoa of regularly fertile bulls. Folia biol. Praha, 17, 357.

LANGENBECK, G. \& GROPP, A. (1973) Vergleichende cytophotometrische DNS-Bestimmungen aneuploider Spermienpopulationen im weiblichen Genitaltrakt. Versammlung der Anatomischen Gesellschaft, Lausanne 1973, No. 68.

Leide, W. \& StollA, R. (1969) Individual difference of UV-DNA in spermatozoa of boars. $\mathcal{7}$. Reprod. Fert. 18, 73, Abstr.

Leide, W., Stolla, R. \& Botzenhardt, A. (1973) The DNA content of morphologically normal and abnormal sperm cells. Proc. 7th Wld Congr. Fert. Steril., Tokyo/Kyoto, 1971, Excerpta med. Int. Congr. Ser. 278, 241-244.

MCFEeLy, R. A. (1967) Chromosome abnormalities in early embryos of the pig. F. Reprod. Fert. 13, 579.

SANDRITTER, W. \& Grosser, K. D. (1964) Quantitative histochemische Untersuchungen an Spermien. Symp. biol. Hung. 4, 63.

STOLcA, R. (1968) Ultraviolettmikrospektrophotometrische Untersuchungen an Samenzellen unter besonderer

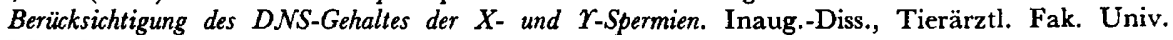
München.

Stolla, R. (1972) Individuelle und tierartliche Unterschiede des DNS-Gehaltes der Spermien. Zentbl. VetMed. 19, 327. 
Tettenborn, U. \& Gropp, A. (1970) Meiotic nondisjunction in mice and mouse hybrids. Cytogenetics, 9,272 .

Walker, P. M. B., Flamm, W. G. \& McLaren, A. (1969) Highly repetitive DNA in rodents. In Handbook of Molecular Cytology, pp. 52-66. Ed. A. Lima-de-Faria. North-Holland, Amsterdam.

ZeCh, L., Evans, E. P., Ford, C. E. \& GropP, A. (1972) Banding patterns in the mitotic chromosomes of the tobacco mouse. Expl Cell Res. 70, 263. 